\author{
PIOTR KONDRACIUK \\ Uniwersytet Pedagogiczny w Krakowie, Polska - Pedagogical University of Cracow, Poland \\ WIKTOR OSUCH \\ Uniwersytet Pedagogiczny w Krakowie, Polska - Pedagogical University of Cracow, Poland \\ AgNIESZKA ŚWIĘTEK \\ Uniwersytet Pedagogiczny w Krakowie, Polska - Pedagogical University of Cracow, Poland
}

\title{
Przedmiot podstawy przedsiębiorczości w opinii uczniów i absolwentów małopolskich szkół ponadgimnazjalnych
}

\section{Basics of Entrepreneurship in the Opinion of Students and Graduates of Secondary Schools in Southern Poland}

\begin{abstract}
Streszczenie: Reforma systemu szkolnictwa wprowadzana obecnie w polskim systemie oświaty niesie ze sobą znaczące zmiany organizacyjne i treściowe w kształceniu w zakresie podstaw przedsiębiorczości. Efektywność tych zmian zależy nie tylko od wprowadzonych uregulowań, lecz w dużej mierze także od sposobu ich wdrażania i uczniowskiej motywacji do realizacji postawionych celów kształcenia. U progu reformy warto pochylić się nad uczniowskim odbiorem dotychczasowej realizacji przedmiotu podstawy przedsiębiorczości w celu podniesienia jakości kształcenia po zmianach systemowych. W niniejszym artykule autorzy przedstawiają wyniki badań opinii uczniów na temat różnych aspektów kształcenia w zakresie przedsiębiorczości: od wskazania preferowanych metod kształcenia, źródeł wiedzy, form pracy, przez wskazanie najistotniejszych umiejętności praktycznych, aż po oceny przydatności całego przedmiotu i kluczowych kompetencji samego nauczyciela. Badania przeprowadzono metodą sondażu diagnostycznego w roku 2018 na grupie badawczej 145 uczniów szkół ponadgimnazjalnych. Wyniki porównywano z wynikami badań przeprowadzanych w latach 2004 i 2011 na zbliżonych grupach badawczych. Analiza wykazała, że aktualnie uczniowie wiele aspektów kształcenia w zakresie podstaw przedsiębiorczości oceniają niezbyt wysoko, a nawet dość krytycznie.
\end{abstract}

\footnotetext{
Abstract: Reform of the school system currently implemented in Polish educational system brings about significant changes in the organisation, as well as in the content of Basics of Entrepreneurship. The effectiveness of changes depends not only on regulations imposed but also, to a large extent, on the way they are implemented and on the student's motivation to pursue main points of education. On the threshold of reform, it is worth to focus on pupils' perception of the subject. The main point is to raise the quality of education after the system changes. Authors of the article introduce the results of analysis of students' opinion on different aspects of education in the field of entrepreneurship: pointing at the preferred methods of education, sources of knowledge, forms of work, and pointing to the most important practical abilities, moreover, measure the use of the whole subject and key-competences of the teacher. The study was conducted with the use of a diagnostic survey in 2018 on a research group of 145 students of high schools. Their results were compared with the ones from years 2004 and 2011 obtained from similar research groups. Analysis has shown that students assess numerous aspects of entrepreneurship education rather poorly.
} 
Słowa kluczowe: ankieta; edukacja; podstawy przedsiębiorczości; szkoła ponadgimnazjalna

Key words: education; high school; Basics of Entrepreneurship; questionnaire

Otrzymano: 25 października 2018

Received: 25 October 2018

Zaakceptowano: 1 marca 2019

Accepted: 1 March 2019

Sugerowana cytacja/Suggested citation:

Kondraciuk, P., Osuch, W., Świętek, A. (2019). Przedmiot podstawy przedsiębiorczości w opinii uczniów i absolwentów małopolskich szkół ponadgimnazjalnych. Przedsiębiorczość - Edukacja [Entrepreneurship - Education], 15(1), 75-87. doi: 10.24917/20833296.151.6

\section{Wstęp}

Zgodnie z rozporządzeniem Ministerstwa Edukacji Narodowej i Sportu z dnia 26 lutego 2002 r. dotyczącym podstawy programowej kształcenia ogólnego, 1 września 2002 r. do polskich szkół ponadgimnazjalnych został wprowadzony przedmiot podstawy przedsiębiorczości. Ramowy plan nauczania zakładał dla tego przedmiotu 60 godz. w cyklu całej edukacji w liceum ogólnokształcącym oraz w technikum (Rozporządzenie Ministra Edukacji Narodowej..., 2012). W. Osuch krótko po jego wprowadzeniu do szkół pisał: „Przedmiot podstawy przedsiębiorczości pomaga zrozumieć młodemu człowiekowi mechanizmy funkcjonowania gospodarki wolnorynkowej. Ponadto kładzie duży nacisk na planowanie przyszłej kariery zawodowej, kształci umiejętności sprawnego komunikowania się oraz przygotowuje młodzież do planowania i realizacji przedsięwzięć w otaczającym go środowisku" (Osuch, E., Osuch, W., 2005). Wprowadzenie do szkół przedmiotu podstawy przedsiębiorczości wymogła na Ministerstwie Edukacji Narodowej i Sportu strategia lizbońska, przyjęta przez Unię Europejską w 2000 r. Podstawowym założeniem strategii było, że postawy przedsiębiorcze mają być kształtowane podczas lekcji z podstaw przedsiębiorczości, a także przez społeczność szkolną (Tracz, Rachwał, 2007). Wiedzę związaną z przedsiębiorczością mieli przekazywać nauczyciele uczący podstaw przedsiębiorczości, a także miała zostać ona włączona w nauczanie innych pokrewnych przedmiotów. Kształcenie uczniów w polskim systemie szkolnictwa miało opierać się na nauce podstawowych teoretycznych zasad funkcjonowania rynku oraz na wykształceniu odpowiednich postaw przedsiębiorczych przez praktykę (Tracz, 2006). Czy cele te udało się osiągnąć? Stojąc u progu wdrażania kolejnej reformy edukacji w szkołach ponadpodstawowych, autorzy postanowili uczynić przedmiotem swoich zainteresowań monitoring stanu przedmiotu przed wdrożeniem kolejnych zmian programowych w kształceniu podstaw przedsiębiorczości. Zarysowany obraz przedmiotu przedstawiono z punktu widzenia najbardziej zainteresowanych - uczniów.

Przedmiotem niniejszej pracy jest ocena podstaw przedsiębiorczości dokonana przez uczniów i absolwentów małopolskich szkół ponadgimnazjalnych. Celem pracy jest przedstawienie wyników badań autorów dotyczących sposobu realizacji i przydatności podstaw przedsiębiorczości. Celami szczegółowymi stało się zbadanie opinii uczniów szkół ponadgimnazjalnych na temat: 
- przydatności przedmiotu podstawy przedsiębiorczości i jego treści kształcenia,

- rodzaju stosowanych na podstawach przedsiębiorczości metod kształcenia i wykorzystywanych środkach dydaktycznych (w szczególności źródeł wiedzy),

- zdobywanych na lekcjach podstaw przedsiębiorczości umiejętności (w szczególności praktycznych),

- oczekiwań uczniów wobec przedmiotu podstawy przedsiębiorczości i jego nauczycieli. Dla osiągnięcia postawionych celów szczegółowych zastosowano metodę sondażu diagnostycznego w postaci badania ankietowego uczniów oraz dokonano analizy porównawczej uzyskanych wyników z wynikami wcześniejszych badań opinii uczniowskich na temat przedmiotu podstawy przedsiębiorczości na zbliżonej grupie i obszarze badawczym w różnych latach. Autorzy powołują się w tym zakresie na pierwsze badania związane z oceną podstaw przedsiębiorczości wykonane przez W. Osucha oraz E. Osuch w 2004 r. (Osuch, E., Osuch, W., 2005), ponowione po kilku latach funkcjonowania przedmiotu w tych samych krakowskich liceach w 2011 r. (Osuch, 2012). Pomocniczo w pracy korzystano również z wyników badań nad oceną podstaw przedsiębiorczości, przeprowadzonych przez K. Ziółkowską-Weiss wśród uczniów w Andrychowie (2014), badaniami nad uczniami i ich postawą wobec podstaw przedsiębiorczości A. Świętek (2012) oraz badaniami nad postawą programową przedmiotu M. Tracz i T. Rachwała (2007).

\section{Metodologia i prezentacja badań}

Prezentowana analiza dotyczy wyników badań uczniowskiej oceny przedmiotu podstawy przedsiębiorczości. Badania zostały przeprowadzone wśród uczniów szkół ponadgimnazjalnych w województwie małopolskim w roku szkolnym 2017/2018. W niniejszej pracy autorzy do przeprowadzenia oceny przedmiotu podstawy przedsiębiorczości wykorzystali metodę badań sondażowych. Uczniowie w swoich odpowiedziach wskazywali zagadnienia, które są dla nich najistotniejsze oraz odpowiadali na pytania związane z jakością prowadzonych zajęć. Ankieta składa się z 19 pytań, wśród których znalazły się pytania zamknięte i otwarte. Badania zostały przeprowadzone przy pomocy narzędzia, jakim jest ankieta elektroniczna, na grupie 145 uczniów ${ }^{1}$.

Badaniami zostały objęte osoby, które w roku szkolnym 2017/2018 uczęszczały do szkół ponadgimnazjalnych, tj. technikum lub liceum. Wśród ankietowanych były 73 kobiety oraz 72 mężczyzn. Aż 71\% badanych stanowili uczniowie lub tegoroczni absolwenci liceów ogólnokształcących. Prawie 39\% badanych w roku szkolnym 2017/2018 uczęszczało do 3 klasy. Około 35\% respondentów stanowili uczniowie klasy pierwszej. Wśród badanych uczniów 31\% zamieszkiwało miasto Kraków. 19\% respondentów jako swoje miejsce zamieszkania wskazało powiat krakowski. Wśród ankietowanych prawie 17\% stanowili uczniowie, którzy zamieszkują Nowy Sącz. Mieszkańcy pozostałych powiatów nie przekroczyli $10 \%$ respondentów.

Około 62\% uczniów ze szkół w województwie małopolskim uważało, że wprowadzenie podstaw przedsiębiorczości było dobrym pomysłem (rycina 1). Przeciwnego zdania było tylko $31 \%$, natomiast pozostałe $7 \%$ nie potrafiło wskazać, czy był to słuszny pomysł, czy nie. W badaniach W. Osucha i E. Osuch z 2004 r. na podobnie postawione pytanie

\footnotetext{
${ }^{1}$ Szczególne podziękowania za pomoc w rozpowszechnianiu ankiety wśród uczniów autorzy składają na ręce Pana Jakuba Kołodziejczyka, dzięki któremu udało się dotrzeć do bardzo szerokiego grona respondentów.
} 
aż 91\% uczniów odpowiedziało, że była to słuszna decyzja (Osuch, E., Osuch, W., 2005). Wyniki badań przeprowadzonych przez jednego z cytowanych autorów w 2011 r. (Osuch, 2012) prezentują natomiast już podobny udział procentowy pozytywnych odpowiedzi, co badania przeprowadzone w 2018 r. Podobne wyniki (wskaźnik 60\%) osiągnięto podczas badań przeprowadzonych w 2013 r. wśród uczniów andrychowskich szkół ponadgimnazjalnych (Ziółkowska-Weiss, 2014). Odsetek uczniów pozytywnie oceniający wprowadzenie przedmiotu do szkoły ponadgimnazjalnej był więc wyższy w okresie wprowadzania przedmiotu do szkół niż po kilku latach jego realizacji.

Zdaniem autorów, podstawową przyczyną takiego stanu rzeczy może być niska przydatność przedmiotu w opinii uczniów. Postanowili więc oni zapytać o to respondentów. Badania wykazały, że uczniowie z województwa małopolskiego uważają, iż tematyka zajęć z podstaw przedsiębiorczości będzie im przydatna w dorosłym życiu. Takiego zdania jest aż 65\% tegorocznych ankietowanych (rycina 2). W 2004 r. wśród badanych uczniów ponad $80 \%$ wskazywało, że prezentowane na lekcjach z podstaw przedsiębiorczości tematy będą przydatne w dorosłym życiu (Osuch, E., Osuch, W., 2005). W 2011 r. uczniowie odpowiadający na takie samo pytanie zaznaczali odpowiedzi pozytywne związane z przydatnością omawianych materiałów z podstaw przedsiębiorczości rzadziej niż w 2004 r. W 2011 r. wynik wynosił już tylko ok. 60\% (Osuch, 2012). W 2013 r. ponad 50\% uczniów andrychowskich szkół ponadgimnazjalnych wskazało odpowiedź twierdzącą na tak samo postawione pytanie (Ziółkowska-Weiss, 2014). Podobnie więc jak w przypadku oceny wprowadzenia przedmiotu do szkoły, odsetek osób wyżej oceniających przydatność przedmiotu również spadł. Warto w tym miejscu podkreślić, że przytoczona ocena „przydatności” przedmiotu jest oczywiście uczniowską opinią. Obiektywne określenie przydatności przekazywanych treści zweryfikuje przede wszystkim rynek pracy, z którym spotkają się badani uczniowie. Ówczesna ocena zdobytej wiedzy i umiejętności oparta będzie na ich konfrontacji z popytem na owym rynku występującym w danym momencie.

Ważnym obszarem wpływającym na postawę uczniów wobec przedmiotu są wprowadzane na nim treści kształcenia. Zdaniem badanych, najciekawsze spośród omawianych tematów lekcji podstaw przedsiębiorczości dotyczyły sytuacji na rynku pracy. Wskazało tak 33\% badanych uczniów (rycina 3), co sugeruje oczekiwania uczniów wobec podstaw przedsiębiorczości. Drugą najczęściej wskazywaną odpowiedzią badanych (21\%) była komunikacja interpersonalna. Uczniowie chcą więc nie tylko być dobrze przygotowani do funkcjonowania na rynku pracy, ale również rozwijać swoje zdolności interpersonalne, które łącznie są kluczowe w znalezieniu dobrej pracy i pomagają w nawiązywaniu kontaktów międzyludzkich. Podobne były oczekiwania uczniów kilka i kilkanaście lat temu. Badania z lat poprzednich również pokazują, że uczniowie wskazywali najczęściej odpowiedzi związane z rynkiem pracy oraz komunikacją interpersonalną jako zakresy treści najbardziej ich interesujące (Osuch, E., Osuch, W., 2005; Osuch, 2012; Ziółkowska-Weiss, 2014).

Obok doboru treści kształcenia istotne z punktu widzenia oceny przedmiotu jest również to, w jaki sposób, a więc przy użyciu jakich środków dydaktycznych (w tym źródeł wiedzy) i metod kształcenia, realizowane są zakładane cele.

Postępująca informatyzacja społeczeństwa przekłada się na zainteresowania uczniów i źródła wiedzy, z których korzystają, przygotowując się do lekcji. W pytaniu dotyczącym źródeł informacji uczniowie mieli możliwość wyboru więcej niż jednej odpowiedzi. Najczęściej wskazywanym źródłem pozyskiwania informacji na lekcje podstaw przedsiębiorczości jest obecnie Internet - wskazało go 77\% badanych w 2018 r. 
Rycina 1. Słuszność wprowadzenia przedmiotu podstawy przedsiębiorczości w szkołach ponadgimnazjalnych w opinii badanych uczniów w 2018 r. (\%)

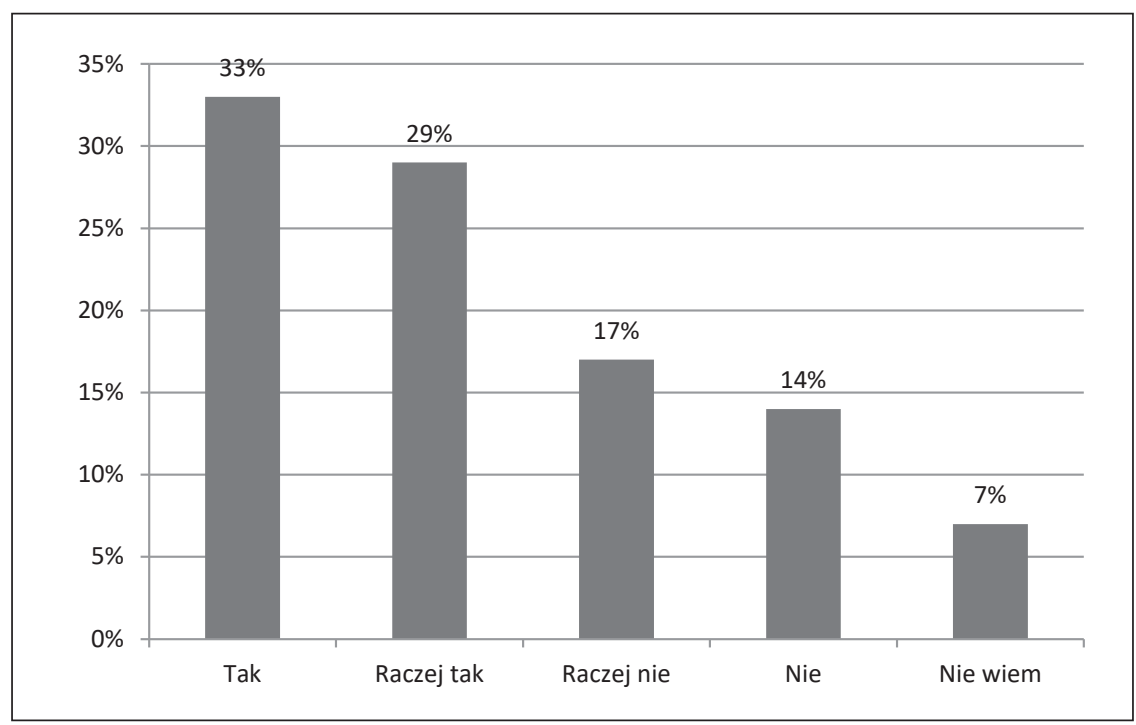

Źródło: opracowanie własne na podstawie badań ankietowych P. Kondraciuka

Rycina 2. Ocena przydatności treści nauczania podstaw przedsiębiorczości w dorosłym życiu w opinii badanych uczniów w 2018 r. (\%)

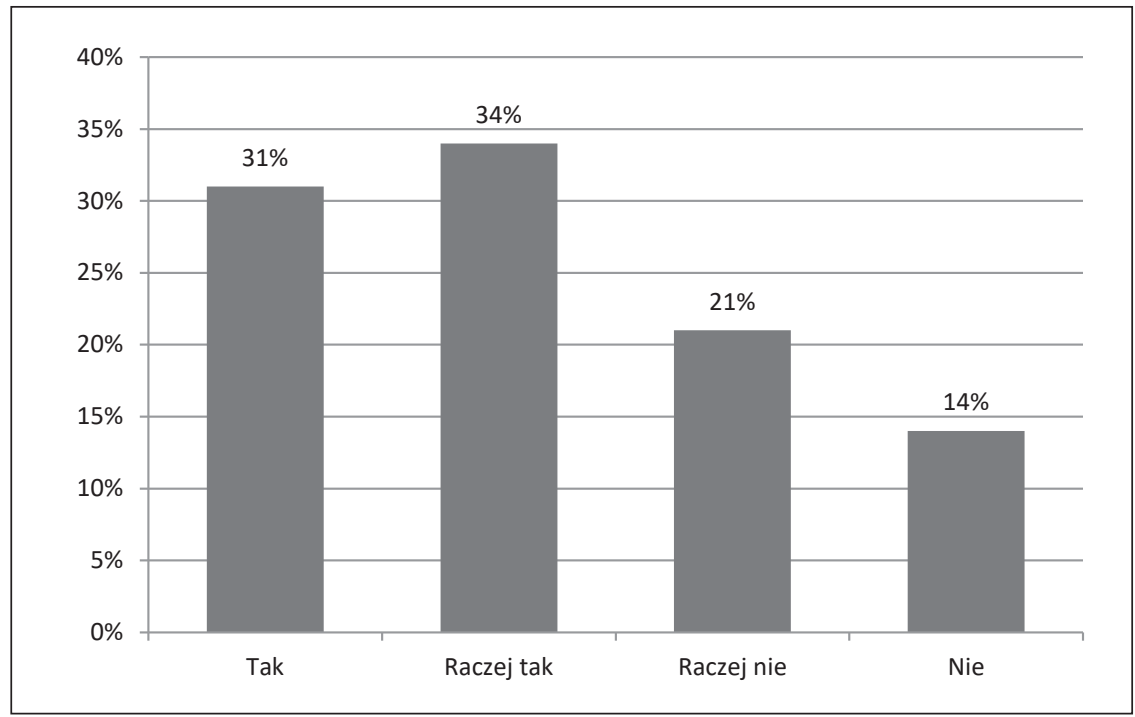

Źródło: opracowanie własne na podstawie badań ankietowych P. Kondraciuka 
Rycina 3. Najciekawsza tematyka przedmiotu podstawy przedsiębiorczości według działów nauczania w opinii badanych uczniów w 2018 r. (\%)

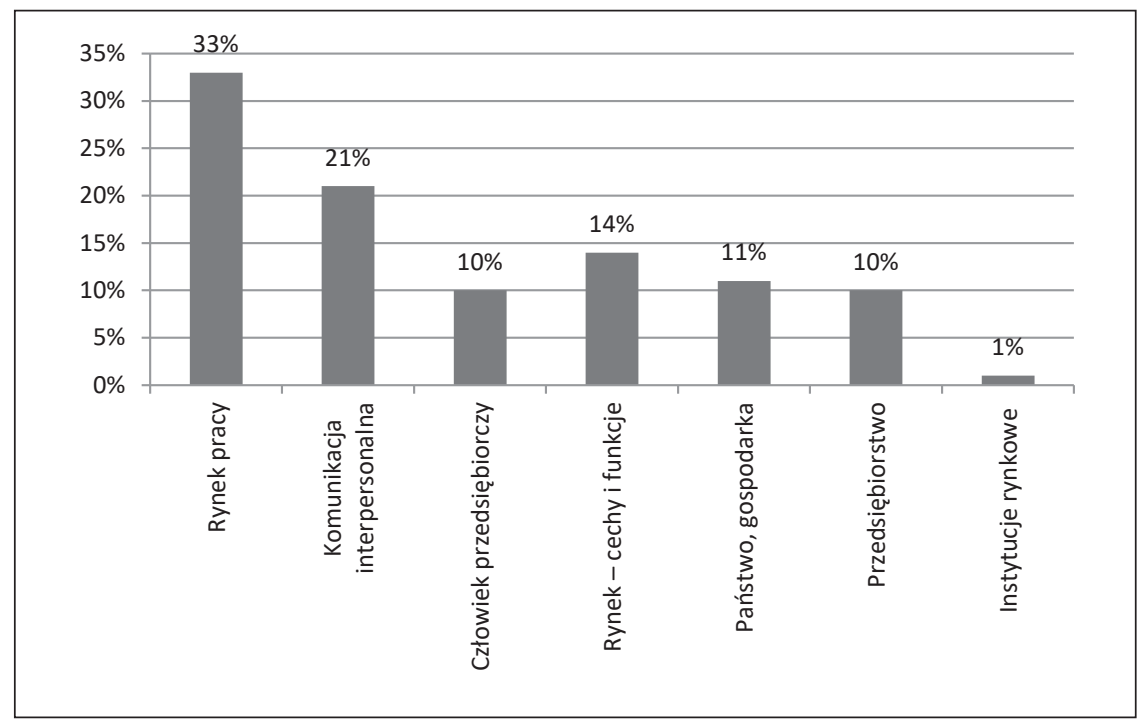

Źródło: opracowanie własne na podstawie badań ankietowych P. Kondraciuka

(rycina 4). Na drugim miejscu znalazł się podręcznik, który otrzymał 42\% odpowiedzi. Pozostałe źródła pozyskiwania informacji nie przekroczyły wartości $10 \%$.

W porównaniu z wynikami badań ankietowych z 2011 r. można zaobserwować spadek odsetka uczniów korzystających ze źródeł papierowych, w tym czasopism (Osuch, 2012). Co zaskakujące, w porównaniu z rokiem 2011 mniejszy jest również odsetek korzystających w przygotowaniu do lekcji z Internetu. W roku 2011 deklarowało jego stosowanie w tym celu 80-100\% uczniów (w zależności od badanej szkoły) (Osuch, 2012). Prawdopodobną przyczyną spadku wykorzystania Internetu jest wzrost świadomości uczniów co do konieczności weryfikowania znalezionych w sieci danych i konieczności stosowania selektywnego podejścia do znajdywanych w Internecie informacji.

W porównaniu z rokiem 2011 utrzymuje się natomiast wysoki wskaźnik korzystających z podręcznika. W roku 2018 korzystało z niego w tym celu 42\% badanych uczniów.

Dla autorów istotna jest również opinia uczniów na temat stosowanych na lekcjach podstaw przedsiębiorczości metod i form kształcenia. Według respondentów, najbardziej adekwatna do prezentowania przez nauczyciela treści z podstaw przedsiębiorczości była wspólna dyskusja. Wskazało ją aż 42\% uczniów (rycina 5). Wspólna dyskusja wymaga szerokiego, merytorycznego przygotowania do tematu nauczyciela (często posiadania przez niego wiedzy na tematy nie do końca związane z samymi podstawami przedsiębiorczości), jak i ucznia. Przekazywanie wiedzy w takiej formie powinno uwzględniać częste przykłady i odwołania do życia codziennego, co pozwoli uczniom lepiej zrozumieć omawiane treści. Jeśli chodzi natomiast o formy pracy, część badanych uczniów uważała, że kompetencje z podstaw przedsiębiorczości dobrze opanowuje się, pracując w grupie. Wskazało tak $17 \%$ respondentów. Łącząc dyskusję z pracą grupową, można otrzymać ciekawe wnioski wysnuwane przez samych uczniów. Na drugim miejscu wśród preferowanych metod kształcenia znalazł się wykład - 15\% odpowiedzi. Forma wykładu nie może być jednak dominującą 
Rycina 4. Najczęściej wykorzystywane źródła zdobywania wiedzy na lekcje podstaw przedsiębiorczości w opinii badanych uczniów w 2018 r. (\%)

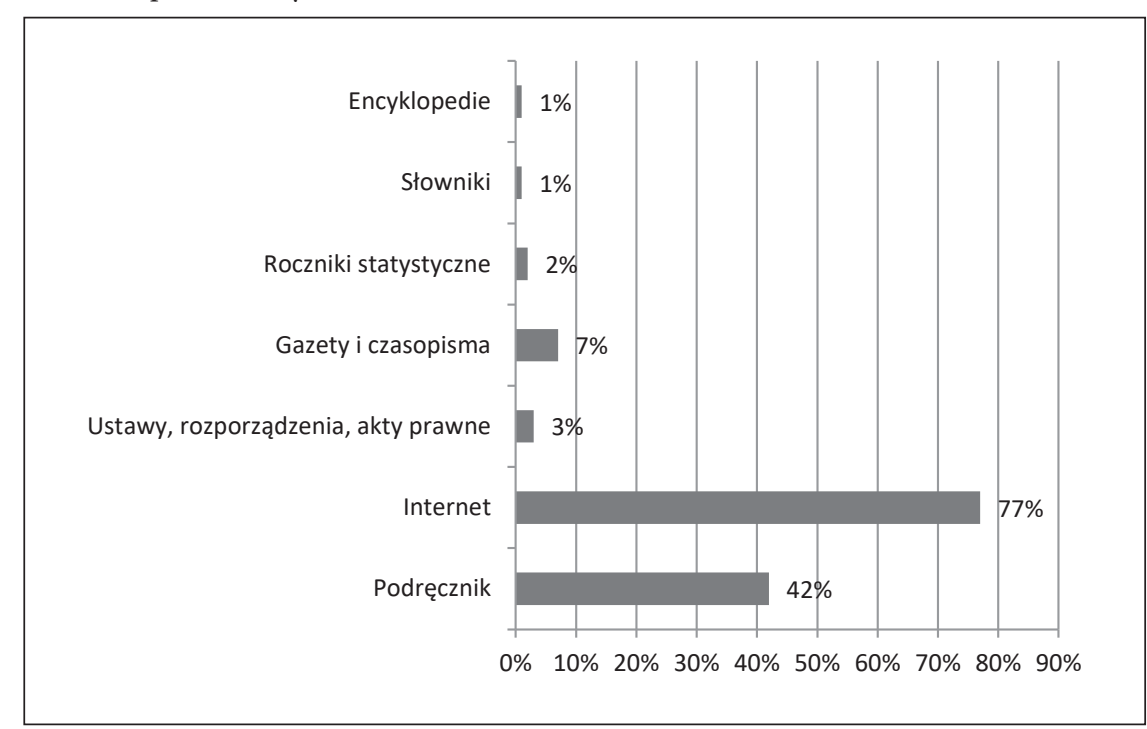

Źródło: opracowanie własne na podstawie badań ankietowych P. Kondraciuka

Rycina 5. Ocena efektywności metod i form kształcenia z podstaw przedsiębiorczości przez badanych uczniów w $2018 \mathrm{r}$.

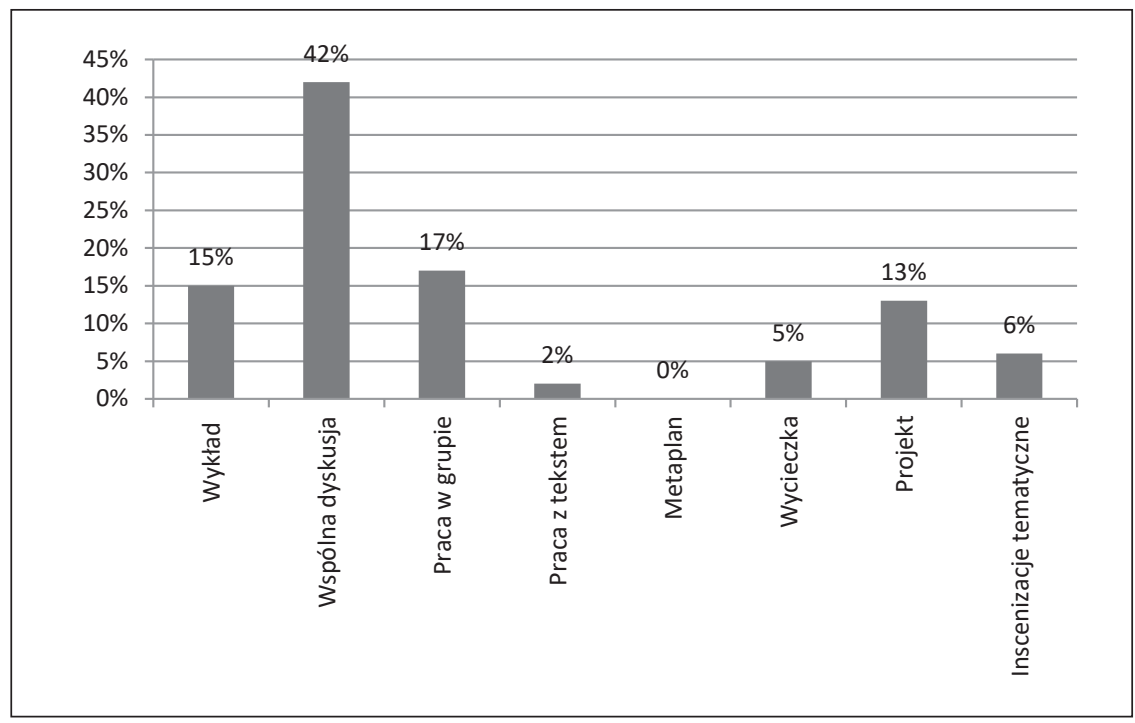

Źródło: opracowanie własne na podstawie badań ankietowych P. Kondraciuka.

klasyczną metodą podającą podczas prowadzonych zajęć z podstaw przedsiębiorczości. Dla porównania warto podkreślić, że uczniowie przebadani w 2004 oraz 2011 r. również wskazywali dyskusję jako najefektywniejszą metodę prowadzenia zajęć z podstaw przedsiębiorczości (Osuch, E., Osuch, W. 2005; Osuch, 2012). 
Rycina 6. Praktyczna ocena wybranych kompetencji na lekcjach podstaw przedsiębiorczości dokonana przez badanych uczniów w $2018 \mathrm{r}$.

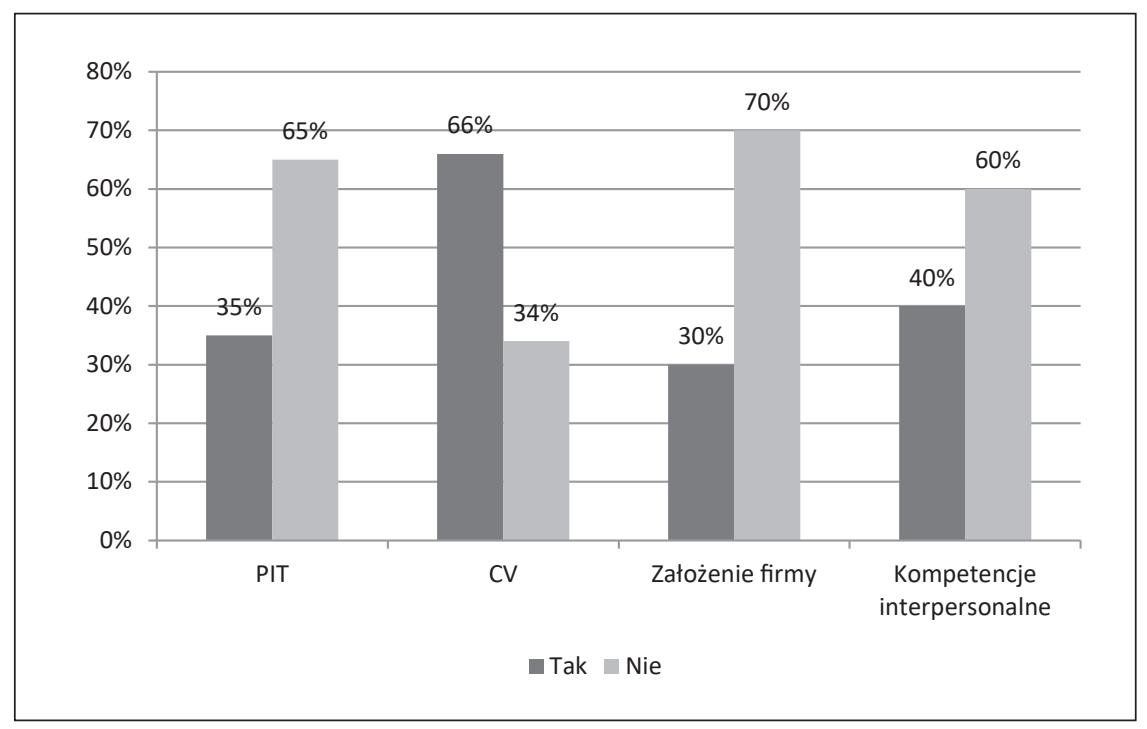

Źródło: opracowanie własne na podstawie badań ankietowych P. Kondraciuka

Tematyka podstaw przedsiębiorczości obejmuje swym zakresem szeroki wachlarz treści, choć nie wyczerpuje ona wszystkich potencjalnie mogących interesować uczniów zagadnień społeczno-ekonomicznych. Autorzy artykułu zapytali uczniów, czy podczas lekcji z podstaw przedsiębiorczości były realizowane inne tematy niż te zawarte w podręczniku. Ponad $60 \%$ uczniów odpowiedziało, że „nie”, ale aż $40 \%$ potwierdziło, że omawiano różne tematy dodatkowe. Na podstawie 145 odpowiedzi uczniowskich należy stwierdzić, że najczęściej pojawiającą się tematyką dodatkową były kryptowaluty oraz inne zagadnienia makroekonomiczne.

Podstawa programowa zakłada również zdobycie przez uczniów podczas lekcji podstaw przedsiębiorczości różnorodnych umiejętności, np. wypełniania deklaracji podatkowej i zakładania własnego przedsiębiorstwa (Rozporządzenie Ministra Edukacji Narodowej i Sportu..., 2002). Uczniowie w odpowiedzi na pytania związane z praktycznym podejściem do omawianych zagadnień najczęściej wskazywali, że po lekcjach z podstaw przedsiębiorczości potrafią napisać CV (66\% ankietowanych) (rycina 6). Około 30\% uczniów odpowiedziało natomiast, że potrafi założyć firmę lub wypełnić poprawnie deklarację PIT. Pozostali uczniowie uważają, że podczas lekcji z podstaw przedsiębiorczości nie nauczyli się ani wypełniać deklaracji PIT, ani zakładać własnej firmy. 40\% uczniów uważa, że dzięki zajęciom z podstaw przedsiębiorczości wzrosły ich kompetencje interpersonalne. Na podobne obszary wiedzy zwracali uwagę uczniowie w badaniach A. Świętek (2012), wskazując za najważniejsze kompetencje, które powinni zdobyć na lekcjach podstaw przedsiębiorczości: napisanie $\mathrm{CV}$, listu motywacyjnego, poprawne przygotowanie do rozmowy kwalifikacyjnej, a także wypełnianie PIT-u i poznanie podstaw funkcjonowania przedsiębiorstwa.

Jak już wspomniano, dla badanych uczniów ważnym celem podstaw przedsiębiorczości jest rozwijanie kompetencji interpersonalnych. Na lekcjach postaw przedsiębiorczości 
Rycina 7. Możliwość wyrażenia własnych poglądów na lekcjach podstaw przedsiębiorczości w opinii uczniów badanych w $2018 \mathrm{r}$.

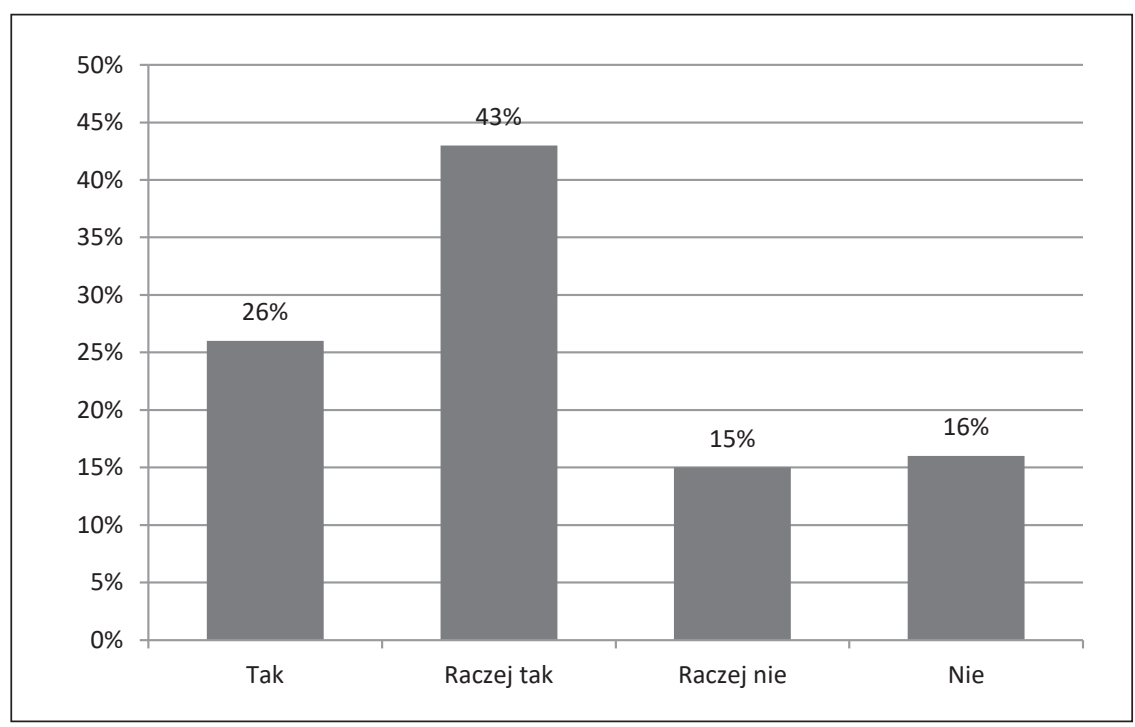

Źródło: opracowanie własne na podstawie badań ankietowych P. Kondraciuka

rozwijają je oni na różnych płaszczyznach. Jedną z nich jest sformułowanie swoich myśli i przedstawianie ich na forum w trakcie wystąpień publicznych. Badanych uczniów zapytano, czy podczas lekcji mogli wyrazić swoje zdanie na tematy związane z różnymi problemami społecznymi i zjawiskami gospodarczymi. Aż 69\% uczniów wskazało, że podczas lekcji z podstaw przedsiębiorczości mogło wyrazić swoje zdanie (rycina 7).

Ostatnia uczniowska opinia, którą wyrażono w badaniach, wskazywała na cechy nauczyciela podstaw przedsiębiorczości uważane przez uczniów za najważniejsze. Uczniowie mogli wskazać w tym pytaniu trzy odpowiedzi. Wyniki pokazują wysokie wymagania uczniów wobec nauczycieli przedmiotu podstawy przedsiębiorczości. Zdaniem największej liczby uczniów najważniejszą cechą dobrego nauczyciela podstaw przedsiębiorczości jest posiadanie wiedzy merytorycznej potrzebnej do prowadzenia przedmiotu (70\% odpowiedzi uczniów). Prócz tego nauczyciel powinien być również osobą kreatywną (59\%) oraz umieć aktywizować uczniów podczas prowadzonych lekcji. Odpowiedzi uczniów badanych w 2018 r. różnią się znacząco od odpowiedzi uczniów badanych w 2004 r. W ówczesnych badaniach ankietowani uczniowie najczęściej wskazywali, że nauczyciel powinien lubić młodzież (Osuch, E., Osuch, W., 2005). Odpowiedź, która znalazła się na pierwszym miejscu w 2018 r. (wiedza merytoryczna) w 2004 r. znajdowała się dopiero jako czwarta spośród najczęściej wskazywanych. Jednak już odpowiedzi uczniów z 2011 r. wskazywały, że cenią oni nauczyciela kreatywnego, który posiada dużą wiedzę merytoryczną (Osuch, 2012).

Czy dotychczasowa realizacja przedmiotu podstawy przedsiębiorczości spełnia oczekiwania uczniów? W 2018 r. aż 55\% badanych przez autorów uczniów wskazywało, że przedmiot podstawy przedsiębiorczości nie spełnił ich wymagań (rycina 9). Uczniowie, podobnie jak w badaniach A. Świętek (2012) wskazali, że oczekują od lekcji podstaw przedsiębiorczości realizacji treści praktycznych. Co niepokojące, wśród oczekiwanych 
Rycina 8. Pożądane cechy nauczyciela podstaw przedsiębiorczości w opinii badanych uczniów w 2018 r.

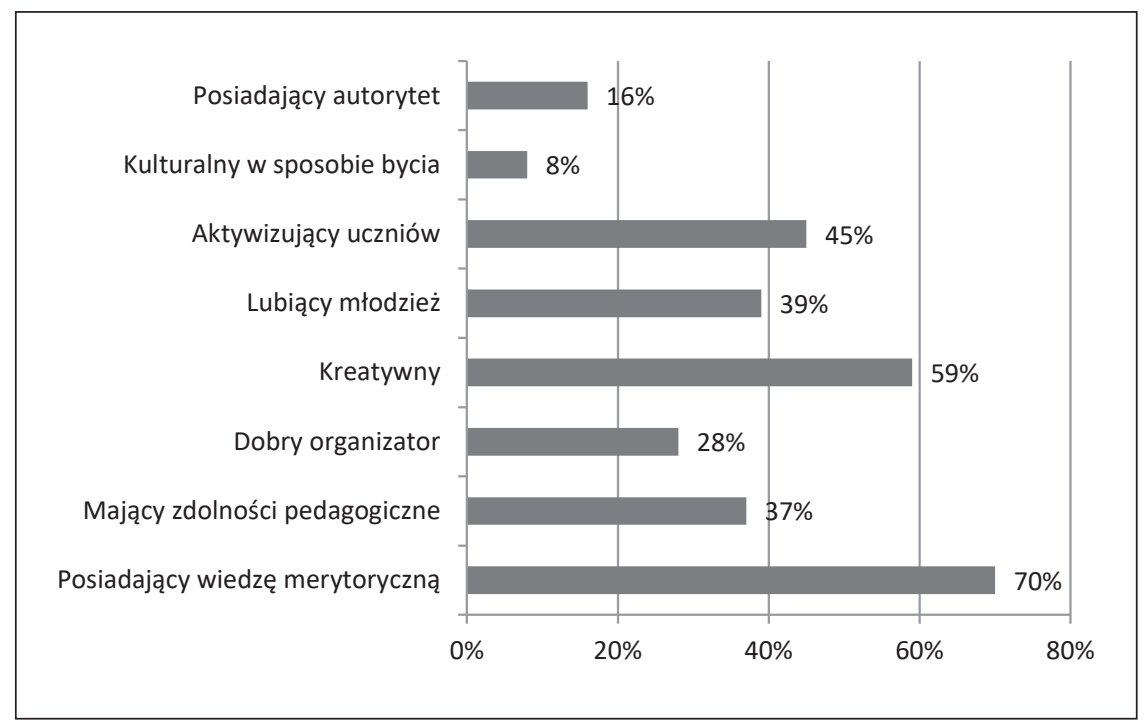

Źródło: opracowanie własne na podstawie badań ankietowych P. Kondraciuka

Rycina 9. Ogólna ocena spełnionych oczekiwań przedmiotu w zakresie nauczania wśród badanych uczniów w 2018 r.

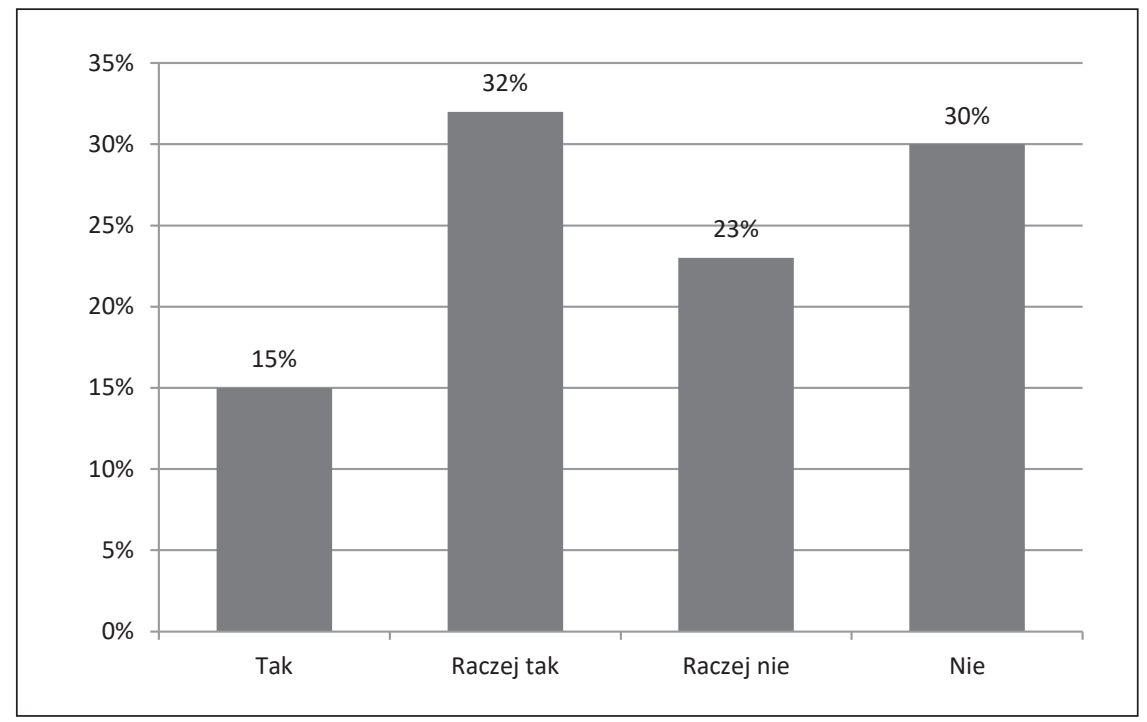

Źródło: opracowanie własne na podstawie badań ankietowych P. Kondraciuka

uczniowie wskazują w zdecydowanej większości treści, które znajdują się w obowiązującej podstawie programowej. Czyżby więc były one realizowane w znikomym zakresie lub zbyt teoretycznie? 


\section{Podsumowanie i wnioski}

Przedmiotem badań zaprezentowanych w niniejszej pracy był monitoring stanu przedmiotu podstawy przedsiębiorczości na krok przed wdrożeniem kolejnych zmian programowych w jego treściach, które niesie za sobą reforma szkolnictwa. Autorzy, zgodnie z celem głównym pracy, przedstawili wyniki badań dotyczące opinii uczniów na temat sposobu realizacji i przydatności przedmiotu podstawy przedsiębiorczości. Oceny przedmiotu podstaw przedsiębiorczości dokonali uczniowie - tegoroczni absolwenci małopolskich szkół ponadgimnazjalnych. Badania, których wyniki zostały zaprezentowane w artykule, zostały przeprowadzone metodą sondażu diagnostycznego, a wyniki uzyskane podczas badań zostały porównane i omówione $\mathrm{z}$ wynikami z krakowskich liceów z lat 2004 oraz 2011, jak również z wynikami z andrychowskich szkół ponadgimnazjalnych (Osuch, E., Osuch, W., 2005; Osuch, 2012; Ziółkowska-Weiss, 2014). Postawiona przez autorów hipoteza badawcza potwierdziła się częściowo.

Uczniowie wysoko ocenili przydatność przedmiotu podstawy przedsiębiorczości, choć ocena ta spadła w porównaniu z odpowiedziami z lat poprzednich. Preferowaną przez uczniów metodą kształcenia podstaw przedsiębiorczości jest dyskusja, a formą pracy - praca grupowa. Uczniowie oczekują od przedmiotu wykształcenia praktycznych umiejętności, co jest przewidziane w podstawie programowej. Niestety, według badanych większość z nich nie potrafiła po lekcjach podstaw przedsiębiorczości wykorzystać niektórych zdobytych umiejętności w praktyce (samemu wypełnić deklarację PIT czy założyć firmę). Około 40\% badanych przyznało natomiast, że wzrosły ich umiejętności komunikacji interpersonalnej i zdobyło umiejętność poprawnego przygotowania dokumentów aplikacyjnych do pracy. Uczniowie stawiają wysokie wymagania wobec nauczycieli przedmiotu, głównie w zakresie posiadanej wiedzy merytorycznej i kreatywności. Uczniowska ocena przedmiotu podstawy przedsiębiorczości jest surowa - większość badanych osób stwierdziła, że nie spełnia on ich oczekiwań. Sugestie uczniów wynikające z badań są cennym materiałem do analizy nie tylko dla nauczycieli, lecz nade wszystko dla twórców pomocy dydaktycznych zgodnych z nową podstawą programową, m.in. autorów programów nauczania i podręczników.

\section{Literatura}

References

Osuch, W. (2012). Podstawy przedsiębiorczości w opinii uczniów krakowskich liceów - szanse i oczekiwania. Przedsiębiorczość - Edukacja, 8, 37-47.

Osuch, E., Osuch, W. (2005), Przedmiot podstawy przedsiębiorczości w opinii uczniów i rodziców na przykładzie wybranych krakowskich szkół. Przedsiębiorczość - Edukacja, 1, 195-202.

Rozporzadzenie Ministra Edukacji Narodowej i Sportu z dnia 26 lutego 2002 r. w sprawie podstawy programowej wychowania przedszkolnego oraz kształcenia ogólnego w poszczególnych typach szkót, Dz.U. $2002 \mathrm{nr}$ 51, poz. 458.

Rozporzadzenie Ministra Edukacji Narodowej $z$ dnia 7 lutego 2012 r. w sprawie ramowych planów nauczania w szkołach publicznych, Dz.U. 2012, poz. 204.

Świętek, A. (2012). Oczekiwania a realia wejścia ludzi młodych na rynek pracy jako wyzwanie dla edukacji z przedsiębiorczości. Przedsiębiorczość - Edukacja, 8, 137-157.

Tracz, M. (2006). Rola i znaczenie podstaw przedsiębiorczości w kształceniu ogólnym. Przedsiębiorczość Edukacja, 2, 222-225. 
Tracz, M., Rachwał, T. (2007). Przedmiot podstawy przedsiębiorczości - założenia realizacji a przygotowanie nauczycieli. Przedsiębiorczość - Edukacja, 3, 286-296.

Ziółkowska-Weiss, K. (2014). Problematyka podstaw przedsiębiorczości w opinii uczniów szkoły ponadgimnazjalnej. Przydatność w życiu czy konieczność nauki?. Przedsiębiorczość - Edukacja, $10,366-377$.

Piotr Kondraciuk, mgr, doktorant, Uniwersytet Pedagogiczny im. Komisji Edukacji Narodowej w Krakowie, Instytut Geografii, Zakład Dydaktyki Geografii. Absolwent Wydziału Geograficzno-Biologicznego Uniwersytetu Pedagogicznego w Krakowie na kierunku geografia z wiedzą o społeczeństwie (2016). Zainteresowania badawcze: turystyka, fanoturystyka, geografia społeczno-ekonomiczna, szkolnictwo.

Piotr Kondraciuk, MA, PhD candidate, Pedagogical University of Cracow, Institute of Geography, Department of Didactics of Geography. Graduated from the Faculty of Geography and Biology of the Pedagogical University of Cracow in Geography with Civics (2016). Research interests: tourism, fantourism, socio-economic geography, education.

ORCID: 0000-0002-8763-3526

\section{Adres/Address:}

Uniwersytet Pedagogiczny im. Komisji Edukacji Narodowej w Krakowie

Instytut Geografii

Zakład Dydaktyki Geografii

ul. Podchorążych 2

30-084 Kraków, Polska

e-mail: piotr.kondraciuk@up.krakow.pl

Wiktor Osuch, dr hab., prof. Uniwersytetu Pedagogicznego im. Komisji Edukacji Narodowej w Krakowie, Instytut Geografii, Zakład Dydaktyki Geografii. Urodzony w Krakowie, absolwent kierunku geografia Uniwersytetu Pedagogicznego w Krakowie, doktor habilitowany nauk społecznych. Jest pracownikiem naukowo-dydaktycznym w Zakładzie Dydaktyki Geografii, Instytutu Geografii Uniwersytetu Pedagogicznego w Krakowie. Prowadzi zajęcia dydaktyczne m.in. z dydaktyki geografii w gimnazjum i szkole ponadgimnazjalnej oraz komunikacji interpersonalnej. Jest opiekunem praktyk zawodowych studentów, zajmuje się koncepcjami i praktyką wychowania, prowadzi seminarium magisterskie. Jego zainteresowania naukowe w obrębie dydaktyki geografii obejmują: kształcenie nauczycieli, praktyki nauczania w szkole, profesjonalne kompetencje nauczycieli geografii, kompetencje kluczowe, metody kształcenia, programy nauczania i podręczniki.

Wiktor Osuch, $\mathrm{PhD}$, associate professor at the Pedagogical University of Cracow, Institute of Geography, Department of Didactics of Geography. Born in Cracow, he has graduated from the Faculty of Geography at the Pedagogical University of Cracow. Associate professor in the field of social sciences, the Deputy Dean of Faculty of Geography and Biology. He is a university lecturer employed in the Department of Didactics of Geography, Institute of Geography at the Pedagogical University of Cracow. Teaching Duties (courses taught): Geography education didactics in lower and upper secondary schools, Interpersonal communication, Student's teaching practice, Concepts of education internships, Geography didactics seminar. Research interest in the field of didactics of geography: teacher's education, teaching practice, geography teacher's professional competences, key competences, teaching methods, geography curriculum and school-books.

ORCID: 0000-0002-1889-3762 


\section{Adres/Address:}

Uniwersytet Pedagogiczny im. Komisji Edukacji Narodowej w Krakowie

Instytut Geografii

Zakład Dydaktyki Geografii

ul. Podchorążych 2

30-084 Kraków, Polska

e-mail: wiktor.osuch@up.krakow.pl Agnieszka Świętek, dr nauk o Ziemi w zakresie geografii, Uniwersytet Pedagogiczny im. Komisji Edukacji Narodowej w Krakowie, Instytut Geografii, Zakład Dydaktyki Geografii. Absolwentka studiów z zakresu geografii ukończonych na Uniwersytecie Pedagogicznym w Krakowie, specjalność: przedsiębiorczość i gospodarka przestrzenna. Adiunkt w Instytucie Geografii Uniwersytetu Pedagogicznego w Krakowie. Jej zainteresowania badawcze skupiają się wokół dwóch tematów: problematyki edukacji z zakresu geografii i przedsiębiorczości, a w szczególności procesu zakładania własnej działalności gospodarczej, wchodzenia młodych ludzi na rynek pracy oraz poziomu życia Romów w Polsce.

Agnieszka Świętek, PhD in Geography, graduated from the Pedagogical University of Krakow with an MA degree in Geography with a specialisation in Entrepreneurship and spatial planning. Associate professor at the Pedagogical University of Cracow, Institute of Geography. Her research interests focus on different research themes: the education in the field of geography and entrepreneurship, in particular the process of starting up own business, young people entering into the labour market and the quality of life of Roma in Poland.

ORCID: 0000-0002-5049-6476

\section{Adres/Address:}

Uniwersytet Pedagogiczny im. Komisji Edukacji Narodowej w Krakowie Instytut Geografii

Zakład Dydaktyki Geografii

ul. Podchorążych 2

30-084 Kraków, Polska

e-mail: aswietek@up.krakow.pl 